\title{
Mutual epistemic dependence and the demographic divine hiddenness problem
}

\author{
MAX BAKER-HYTCH \\ Faculty of Philosophy, University of Oxford, Radcliffe Humanities, Oxford, OX2 6GG, UK \\ e-mail: max.baker-hytch@philosophy.ox.ac.uk
}

\begin{abstract}
In his article 'Divine hiddenness and the demographics of theism' (Religious Studies, 42 (2006), 177-191) Stephen Maitzen develops a novel version of the atheistic argument from divine hiddenness according to which the lopsided distribution of theistic belief throughout the world's populations is much more to be expected given naturalism than given theism. I try to meet Maitzen's challenge by developing a theistic explanation for this lopsidedness. The explanation I offer appeals to various goods that are intimately connected with the human cognitive constitution, and in particular, with the way in which we depend upon social belief-forming practices for our acquisition of much of our knowledge about the world - features about us that God would value but that also make probable a lopsided distribution of theistic belief, or so I argue.
\end{abstract}

\section{Introduction}

Stephen Maitzen (2006) has developed a version of the atheistic argument from divine hiddenness that focuses not upon the mere existence of non-culpable non-belief in God, but rather, upon the lopsided manner in which non-culpable non-belief appears to be distributed across the globe. ${ }^{1}$ He claims that this version of the argument from divine hiddenness can circumvent a whole range of theistic responses to J. L. Schellenberg's (1993, 2007) version of the hiddenness argument - responses which seek to explain instances of non-culpable nonbelief in terms of various moral, spiritual, or epistemic deficiencies on the part of human individuals. Reflecting on a collection of essays on divine hiddenness in which a number of theistic philosophers present responses to Schellenberg (see Howard-Snyder \& Moser (2002)), Maitzen writes that

Those contributors who explain all non-belief in terms of the epistemic or moral defectiveness of non-believers never address the question 'Why does that defectiveness vary dramatically with cultural and national boundaries?'. Moreover, given the widely held assumption that, generically speaking, epistemic and moral defects are evenly distributed among the world's peoples, it is hard to see how that

1. Theodore Drange (1991) has advanced an 'argument from non-belief' which has some similarities with Maitzen's, though Drange's argument only targets versions of soteriologically exclusivist versions of Christian theism, whereas Maitzen's argument is meant to apply to theism generally. 
question could be answered. Those contributors who grant the existence of blameless non-belief, and try to explain why God tolerates it, never ask why God tolerates it so unevenly. (Maitzen (2006), 180)

The version of the argument from hiddenness that Maitzen is offering seems best construed as a probabilistic rather than deductive argument against the existence of God. Maitzen isn't claiming that the lopsided distribution of theistic belief is logically inconsistent with theism, but rather, that such a distribution is not at all what we would expect to see given theism. I take it that by 'theism' Maitzen means monotheism and by 'theistic belief' he means monotheistic belief, and I shall use the terms in the same way. So, where $\mathrm{E}$ is the proposition that the distribution of theistic belief is heavily lopsided, Maitzen's comparative likelihoods claim would seem to be as follows:

\section{(C) $\operatorname{Pr}(E \mid$ theism $)$ is much lower than $\operatorname{Pr}(E \mid$ naturalism $){ }^{2}$}

Now, (C) is consistent with its being true that theism is more probable than naturalism when everything else is taken into consideration. Still, the truth of (C) would be bad news for the theist in that it would place increased pressure upon her to show that other salient bits of evidence favour theism over naturalism.

My aim in this paper, then, is to try to show that $(\mathrm{C})$ is significantly less plausible than Maitzen supposes it to be. To that end I shall argue that it is likely that God would want human beings to be significantly dependent upon one another for acquiring much of their knowledge about the world. Such mutual epistemic dependence makes possible a range of goods that God would likely want to realize, so I shall argue, but it also has the effect of tending to produce a geographical 'clustering' of particular sets of religious beliefs among particular groups of people. This story is meant to go a substantial way towards explaining why God would permit E to obtain. ${ }^{3}$

2. In favour of interpreting him as making this claim about comparative likelihoods, Maitzen states in a subsequent paper, in which he responds to Jason Marsh's (2008) response to the original paper, that 'I've never alleged the logical incompatibility of theism and the lopsided distribution of theistic belief we observe in the world... All I claim is that the lopsided distribution of theistic belief is less surprising on naturalistic explanations than on theistic ones' (Maitzen (2008), 475, 477).

3 To be sure, such a story doesn't fully explain E, for it doesn't address the undoubtedly troubling question to which Jason Marsh (2013) has drawn attention concerning why early human societies apparently lacked anything that closely resembled theistic belief. Still, insofar as it constitutes a significant partial explanation for $\mathrm{E}$ and insofar as it is plausible, the story I am about to present ought to detract substantially from the plausibility of $(\mathrm{C})$. 


\section{Mutual epistemic dependence}

Let's begin by getting clearer on what it might mean to say that humans are mutually epistemically dependent. Humans appear to be cognitively constituted in such a way that it is a practical necessity that we rely upon testimony for much of what we know about the world and in such a way, moreover, that we are liable to be significantly influenced by what those around us believe, particularly when it comes to matters that aren't readily susceptible to empirical investigation, including religious matters. This is the actually obtaining state of affairs that I am calling 'mutual epistemic dependence' (MED, for short). Thomas Reid (1997) is well-known for having drawn attention to these features of human nature, at a time when many of his philosophical near-contemporaries were actively seeking to engender a deep suspicion about testimony as a source of knowledge. In particular, Reid drew attention to two tendencies that he recognized as being native to human beings: the tendency to tell (what we take to be) truth and the tendency to trust what others tell us. ${ }^{4}$ More generally Reid points out that our pursuit of epistemic goods is a deeply communal enterprise. With the exception of knowledge about our own mental states, immediate surroundings, memories of our past experiences, and a handful of self-evident truths, humans are cognitively constituted in such a way as to be significantly dependent for our acquisition of a wide range of truths upon a massive division of epistemic labour amongst ourselves.

Recent cognitive science is further shedding light on the nature of our dependence on testimony. Justin Barrett points to two types of cognitive bias that play a significant role in determining how plausible we will tend to find a given item of testimony (Barrett (2011), 52-72). On the one hand there are context biases, having to do with the apparent character of the testifier and the circumstances in which the testimony is presented. Examples of context biases include conformity biases which incline us to fall in line with the majority opinion of our peers, prestige biases which incline us to trust those of high standing in our communities, and similarity biases which incline us to trust those who appear to be similar to ourselves in various important respects.

On the other hand, there are content biases, having to do with the intrinsic plausibility of what is being asserted by a testifier. A key theoretical postulate of contemporary cognitive science is that the operation of the human mind involves two parallel processing systems, namely, the intuitive system (System 1) and the reflective system (System 2). According to Daniel Kahneman (2003, 2013), one of the foremost proponents of this 'dual-processing' view of cognition, the intuitive system is quick, effortless, emotion-laden, and automatic, compared with the reflective system, which is slow, deliberate, and involves significant mental

4. Reid calls these tendencies, respectively, the 'principle of veracity' and the 'principle of credulity' (Reid (1997), 194). 
effort. The operations of the intuitive system and the reflective system are thought to interact in several important ways, including that the deliverances of intuitive cognition constrain what an individual is liable to endorse upon reflection, as well as that intuitive judgments are liable to serve as defaults for reflective beliefs in the absence of consciously accessible reasons for rejecting them. ${ }^{5}$ So, for example, if someone tells you about a species of animal of which you have never previously heard and then goes onto explain how these animals give birth to babies who are physically similar to themselves, this latter claim is likely to strike you as highly plausible, and your judgment here can be explained by the fact that the claim in question comports very well with your intuitive expectations concerning living things, sometimes known as 'folk biology'. A noteworthy hypothesis in the cognitive science of religion is that certain ideas that deviate in small but striking ways from our intuitive expectations about the world are especially liable to be remembered and passed on via testimony. Pascal Boyer has termed such ideas 'minimally counterintuitive', and has suggested that the minimally counterintuitive character of many religious concepts - for instance, concepts of deities who are in many ways human-like but have striking superpowers such as invisibility and the ability to read minds - is part of the explanation for why religious beliefs are so easily spread via testimony (Boyer (2001), 87100).

It should not come as a surprise that mutually epistemically dependent creatures such as we are tend to be copycats, so to speak. More specifically, it should not come as a surprise that certain propositions concerning the nature of ultimate reality would be believed by many such creatures in some communities and by hardly any of them in other communities. After all, such creatures have bodies, and given that they have bodies and hence must be located in particular physical locations alongside some of their fellow creatures and not others, and given that they form communities that are mutually isolated to some degree, the extent to which some creature $\mathrm{A}$ is liable to be influenced by the testimony of another creature B depends greatly upon the physical proximity of A to B. And insofar as such creatures are social in nature, the degree to which they trust the testimony of others will be influenced by the degree to which they personally know and trust others. What's more, propositions concerning such matters as metaphysics, religion, politics, and morality tend to be such that, for creatures who are subject to such cognitive limitations as we are, it is frequently far from obvious how to adjudicate the truth or falsity of these sorts of propositions with reference to perceptual experience. So, even despite the fact that all such creatures share broadly the same range of perceptual experiences, and even given that all such creatures are naturally inclined to accept broadly supernaturalistic claims (as current cognitive science of religion alleges), ${ }^{6}$ these facts significantly

\footnotetext{
5. It should be noted that, while influential, the dual-processing framework is controversial.

6. See Barrett (2011) and Boyer (2001).
} 
underdetermine which religious propositions such creatures will end up believing. Therefore, whereas one would not expect much divergence among such creatures with respect to their beliefs about the physical properties of publicly observable, medium-sized physical objects, it would not be at all surprising to find that they diverge considerably with respect to the contents of their religious beliefs. And since they are liable to be influenced most heavily by the testimony of those who are most physically proximate, and perhaps in particular, by those whom they personally trust and respect, we would expect to see that the religious beliefs of such creatures tend to cluster up geographically and culturally in something a lot like the way that we in fact do observe that human religious beliefs cluster up. For these reasons it is very plausible that

(1) $\operatorname{Pr}(\mathrm{E} \mid \mathrm{MED})$ is high.

Of course, this much doesn't tell us anything about the ratio of $\operatorname{Pr}(E \mid$ naturalism $)$ to $\operatorname{Pr}(\mathrm{E} \mid$ theism). The naturalist too will surely appeal to something like MED in order to explain E. The interesting question to which I now turn is whether $\operatorname{Pr}(\mathrm{MED} \mid$ naturalism $)$ is much higher than $\operatorname{Pr}(\mathrm{MED} \mid$ theism $)$.

\section{Mutual Epistemic Dependence and Competing Goods}

Let's grant that it is not very surprising given naturalism that there exist embodied beings with roughly our cognitive constitution, that is, that it is not very surprising on naturalism that MED obtains. Doubtless some theists would wish to dispute this by appealing to thought that consciousness, which is obviously a necessary condition for MED, is highly improbable on naturalism. But here I am aiming to establish only the much more modest claim that

(2) $\operatorname{Pr}(\mathrm{MED} \mid$ theism) isn't much lower than $\operatorname{Pr}(\mathrm{MED} \mid$ naturalism).

To that end, I shall now try to show that it would be fairly unsurprising given theism that there should exist creatures who are cognitively constituted roughly as humans are.

If God exists and chooses to create intelligent, morally sensitive, free creatures, he has open to him a range of possible types of such creatures, of which humans are just one type. There are possible races of creatures who have significantly greater cognitive powers than us - for instance, who possess the ability to read minds, to perceive spatially remote occurrences, and so on. At the same time, there are possible races of intelligent, morally sensitive, free creatures who have significantly lesser cognitive powers than us - for instance, who lack even our ability to make various competent inferences about one another's beliefs, desires, and intentions from their facial expressions, tones of voice, and 
body language. If it could be shown that our cognitive constitution is the best one for God to bestow upon a race of intelligent, morally sensitive, free creatures, then the probability that God would create beings with such a cognitive constitution (i.e. that God would bring about MED), given that he creates intelligent, morally sensitive, free creatures at all, would be 1 . But I can't think of a way to show that our cognitive constitution is the best one for a race of intelligent, morally sensitive, free creatures to have. Indeed, I doubt very much that there is a best cognitive constitution for such creatures to have.

What I'm going to suggest is that there are certain trade-offs between competing goods that would have to be made were God choosing what kind of cognitive constitution to bestow upon a race of intelligent, morally sensitive, free creatures. (Goods here are to be understood as including preventions of harms or evils.) Whilst there are clearly undesirable extremes wherein one good is realized to the excessive detriment of another good with which it is in competition, in between the extremes lies a range of possible configurations none of which is clearly better than another, but any of which is clearly better than the extremes. I now want to suggest that MED - the state of affairs in which humans have roughly the sort of cognitive constitution that we actually do; in which we are mutually epistemically dependent to roughly the degree that we are - is such as to strike a balance between competing goods that clearly lies between two undesirable extremes, so that it would be unsurprising were God to bring about a race of creatures who are so constituted. It would be unsurprising, that is, were God to bring about MED. To that end, I shall discuss three pairs of competing goods, and in each case will try to show that our actual cognitive constitution very plausibly makes for a balance between them that is favourable, even if not uniquely optimal.

\section{Exercising interpersonal trust vs. being invulnerable to deception}

By 'interpersonal trust' I mean the following: a person $S$ places trust in another person $R$ just in case $S$ is less than certain that $R$ has the property of being benevolently disposed towards $S$ in some respect - for instance, the property of being a faithful spouse to $S$, the property of being willing and able to catch S's fall, the property of intending to make good on a promise to S, the property of loving $S$, the property of being honest towards S, and so on - and yet, despite her uncertainty, $S$ undertakes action(s) that will have a favourable outcome for $\mathrm{S}$ only if $\mathrm{R}$ does indeed possess the property in question. ${ }^{7}$ Now, I don't intend this as a theory about ordinary language usage of the term 'trust', which may well have a plurality of interconnected meanings. ${ }^{8}$ I simply want to

\footnotetext{
Buchak's (2014) decision-theoretic analysis of faith is along these lines.

See Simpson (2012).
} 
suggest that the activity that I have stipulated herein as the meaning of 'interpersonal trust' is one in which it is very valuable for humans to engage.

Clearly enough, having the opportunity to engage in interpersonal trust, as I have defined it, requires having some degree of uncertainty about the relevant properties of the person in whom one places one's trust. And this in turn requires that we are not so constituted as to be able very easily to acquire certainty on a wide range of propositions concerning one another's thoughts, intentions, feelings, capabilities, and so on, independently of what others tell us about themselves. In short, having significant opportunities to place interpersonal trust in one another requires our being cognitively limited in roughly the ways in which we in fact are: in particular, it requires that we cannot simply read one another's minds, and more generally, that others can do things in private about which we cannot learn independently of their testimony.

Now, the good of having opportunities to trust one another is in tension with the good of not being vulnerable to deception or betrayal by one another. The more we are cognitively constituted so as to have to trust one another, the more we will be at risk of being duped by one another. But the degree to which humans are in fact dependent upon one another's testimony for learning about one another and the world is such as to permit a favourable balance between having significant opportunities to place trust in one another, on the one hand, and yet still being capable of discerning enough about one another via nontestimonial means so as to prevent us from being excessively at risk of deception by one another, on the other hand. Consider, for example, the degree to which we are able, independently of testimony, to learn about one another's inner lives and about what is going on elsewhere in the physical world. If we were a lot more capable in these regards than we actually are - if, say, we could read one another's minds, had X-ray vision, and could immediately perceive events in distant spatial locations - we would rarely have any opportunity to place trust in others, and what's more, it would be very difficult indeed for us to keep things to ourselves, which in turn would make it very difficult to engage in the sorts of free actions for good or ill that require that our thoughts and intentions are not immediately obvious to everyone around us. On the other hand, if we were much less able in these regards - if, say, we were unable to make the sorts of competent inferences that we often make concerning people's thoughts, intentions, and feelings from observing their facial expressions, body language, and tones of voice - it would be far harder to make competent initial judgments about whether to trust a person, which in turn would render us excessively vulnerable to other's evil intentions. 
Sharing responsibility for one another's acquisition of epistemic goods vs. practicing epistemic self-reliance

By epistemic goods, I have in mind such goods as true belief, justified belief, knowledge, understanding, wisdom, and so on. ${ }^{9}$ Sharing responsibility for one another's acquisition of such goods adds substantially to the range of morally significant free actions that are available to humans, and hence, to the range of morally good states of affairs that humans are able to realize. ${ }^{10}$ Specifically, it affords a human person the morally significant choice between depriving others of their knowledge or sharing it with them, between willfully distorting or suppressing the truth and trying their best to relay it faithfully, between cooperating with others in the search for truth or trying to thwart others in that search, and so on. As Robert Roberts and Jay Wood rightly note,

It is possible to be generous in the conduct of intellectual practices, or stingy and greedy, just as in the handling of material and other goods. The reason is that the intellectual life has its own set of goods, and these can be shared with others and given to others, or grasped and hoarded for oneself. (Roberts and Wood (2007), 292)

Now, the good of our sharing responsibility for one another's acquisition of epistemic goods is obviously in tension with what some epistemologists also regard as a significant good, namely, epistemic self-reliance (see, for instance, Fricker (2006)). To practice epistemic self-reliance is to try to figure things out by oneself. Roughly speaking, the more our cognitive constitution is such as to force us to be epistemically reliant upon one another, the fewer opportunities we will have to practice epistemic self-reliance, and vice versa. Ryan Byerly (2014) has recently argued that the value of epistemic self-reliance lies in the way in which cognitive successes that are attained solely through one's own cognitive competences typically count as greater cognitive achievements than they would do were those same successes the result of relying upon others. I don't wish to dispute this, but the way in which humans are actually cognitively constituted is evidently somewhere in between the twin extremes of being so cognitively weak that we are forced to rely upon one another almost continually and being so cognitively well-endowed that we seldom need help from others in order to get at the truth. Our actual cognitive constitution seems to be such as to permit a rather favourable balance between the competing goods of sharing responsibility for one another's intellectual wellbeing and practicing epistemic self-reliance. What's more, it looks as though the sorts of self-reliant cognitive achievements that we find valuable are frequently such that they manifest intellectual virtues

9. For a comprehensive list of epistemic goods, see Roberts and Wood (2007), 32-58.

10. Swinburne goes so far as to suggest that 'We cannot do good or harm to each other in many ways without humans already cooperating in the acquisition of knowledge' (Swinburne (1998), 147). 
that have been acquired and cultivated through a host of intellectual practices that involve reliance upon others: reliance, for instance, upon one's schoolteachers and parents, and later on, one's colleagues and interlocutors. ${ }^{11}$ Our being mutually epistemically dependent to roughly the degree that we in fact are seems to afford us a wide range of opportunities for cultivating the intellectual virtues that are required for exercising epistemic self-reliance. This leads me to discuss one last pair of competing goods.

\section{Opportunities to acquire, practice, and perfect the intellectual virtues vs.}

freedom from intellectual obstacles and challenges

Just as there are virtues of character pertaining to moral conduct, so too there are virtues pertaining to our intellectual conduct, pertaining to the manner in which we go about acquiring and managing our beliefs about the world and transmitting the contents of those beliefs to others. Jason Baehr defines an intellectual virtue as 'a character trait that contributes to its possessor's personal intellectual worth on account of its involving a positive psychological orientation toward epistemic goods' (Baehr (2011), 102). Roberts and Wood have suggested that 'An intellectual virtue is an acquired base of excellent epistemic functioning' (Roberts and Wood (2007), 95). Lists of intellectual virtues presented by Linda Zagzebski (1996), Roberts and Wood (2007), and Baehr ((2011), 17-32) include such character traits as intellectual justice, fair-mindedness, impartiality, openmindedness, intellectual integrity, honesty, intellectual humility, transparency, self-awareness, self-scrutiny, intellectual generosity, and intellectual courage.

Just as our having the opportunity to acquire, practice, and perfect a wide range of moral virtues requires that human life unfold against a backdrop of struggle and adversity, ${ }^{12}$ similarly, our having the opportunity to acquire, practice, and perfect a wide range of intellectual virtues requires that our intellectual lives - our strivings to acquire intellectual goods - take place against a backdrop of intellectual adversity: a backdrop which includes such things as persistent disagreements over deeply important matters; withholding or suppression of information by those who occupy positions of power; uncertainty about the best means to acquire important truths about the nature of reality; temptation to deceive ourselves about our own motivations, including our motivations for believing various things; pressure to conform our opinions to a prevailing consensus; pressure to be untruthful in our dealings with others in order to gain a competitive advantage; temptation to malign a person rather than

11. See Pritchard's (2013) account of the role of communal epistemic practices in education in cultivating the cognitive abilities that are required for the highest-grade cognitive achievements. See also Roberts and Wood (2007), 113-150.

12. This thought plays a central role in so-called 'soul-making' theodicies, notable examples of which include Hick (1979), and more recently, Stump (2010). Dougherty (2014) has notably applied a similar line of thought in developing a theodicy for the suffering of non-human animals. 
engage her arguments; and so on. What's more, the existence of such obstacles, challenges, and temptations requires that our cognitive capacities be limited in some of the following sorts of ways: in particular, that we are significantly dependent upon one another for acquiring a great deal of the truths that are needed for living a worthwhile life; that our perceptual experience of the world is generally insufficient to decisively settle a wide range of deeply important questions, such as those pertaining to politics, morality, metaphysics, and religion; that our opinions and plausibility judgments - especially on questions that cannot be decisively settled through empirical investigation - are prone to be influenced by the norms and consensuses that prevail within the intellectual communities in which we find ourselves; that our reasoning processes are prone to be influenced by unconscious, emotional biases, which must be effortfully overcome.

Having a significant range of opportunities to acquire, cultivate, and perfect the intellectual virtues seems to require that the degree to which we are subject to the various aforementioned obstacles lies somewhere in between two extremes. To illustrate what I mean, consider the following analogy. Having the opportunity to become skilled at driving a car requires that one gets some practice at driving in challenging conditions: in bad weather; in built up areas; in heavy traffic; whilst carrying noisy passengers. Part of the skill of driving is having the ability to respond appropriately to such challenges. But if these challenges are too severe - if, say, one's passengers continually try to distract one, the weather is so dreadful that visibility is almost nil, pedestrians are frequently running out into the road at random, other vehicles are continually making hazardous lane changes all around - then it will be extremely hard to acquire in the first place the skills involved in being a good driver. One will not even be able to get off the ground. On the other hand, if the challenges are too insubstantial - if, for instance, one only ever drives around an empty practice circuit inside a warehouse - then one won't ever be called upon to respond to adverse circumstances, the skillful handling of which is involved in being a good driver. The same seems to be true of acquiring virtues of intellectual character. Acquiring them requires that one face intellectual challenges and obstacles that are neither too severe nor too insubstantial. And it looks plausible that the way in which humans are actually cognitively constituted is such as to present us with an array of intellectual challenges and obstacles that is not so severe that we can scarcely make any headway in acquiring virtues of intellectual character, nor is so insubstantial that we seldom encounter any situations that call for the exercise of such virtues.

Let's take the virtue of intellectual courage as an example. Baehr suggests that intellectual courage is (at least roughly and generally) a matter of (1) pursuing an intellectual good (2) despite the fact that doing so involves a certain 
threat or potential harm to oneself (Baehr (2011), 169). ${ }^{13}$ Consider a race of creatures who are cognitively much stronger than us: for instance, who are constituted in such a way that each one on their own can arrive at knowledge of almost all of the truths they desire or need to know, without relying upon testimony. Such creatures would seldom have cause to exercise intellectual courage. We humans, in virtue of our more modest epistemic capabilities, fairly often encounter opportunities to risk our reputation or wellbeing in some way (even if only in a small way) in order to improve the epistemic situation of others. In particular, due to the ways in which we are cognitively limited we fairly frequently have opportunities to exercise intellectual courage in proclaiming (what we take to be) truths of which others are ignorant or towards which others are hostile, and furthermore, our cognitive limitations provide us with opportunities to exercise courage in the sense of engaging in intellectual inquiries which may turn out to be dead-ends or to put our reputations and wellbeing at risk. Displays of such courage might include communicating to a friend some truth that is hard for her to hear, holding firm to a view that one's peers think contemptible or laughable, engaging in a risky investigation to uncover some truth that has been wilfully suppressed by others, or perhaps more dramatically, blowing the whistle on institutional malpractice. Presumably, the extremely cognitively strong creatures I mentioned would seldom have opportunities to benefit the epistemic situations of their fellows in these ways. On the other hand, consider a race of creatures who are much cognitively weaker than us: who, for instance, have such weak cognitive faculties that they can decisively establish very little of significance by way of them, or are so prone to conformity that for any one of them to think independently of their peers requires monumental effort, or who are subject to all sorts of overwhelmingly powerful, error-prone biases in their reasoning processes. Though these creatures might well face an even greater array of situations than we do in which they could benefit the epistemic situations of their peers by risking their own wellbeing, their extreme cognitive frailties will tend overwhelmingly to prevent them from usefully doing very much to alleviate the epistemic impoverishment of their fellows. ${ }^{14}$

If, as I have argued, we have good reason to think that (1) $\operatorname{Pr}(E \mid M E D)$ is high and that (2) $\operatorname{Pr}(\mathrm{MED} \mid$ theism) isn't much lower than $\operatorname{Pr}(\mathrm{MED} \mid$ naturalism, then we have good reason to doubt that $\operatorname{Pr}(\mathrm{E} \mid$ theism $)$ is much less than $\operatorname{Pr}(\mathrm{E} \mid$ naturalism $)$, and hence to doubt Maitzen's contention. In the remainder of the paper I want to try to address some potential objections to (2) before

13. For an extended discussion of intellectual courage, see Roberts and Wood (2007), 215-235.

14. Possessing an intellectual virtue does, after all, require that one fairly frequently succeeds in one's exercise of that virtue. A virtue is a kind of ability, and as John Greco notes, having an ability with respect to some range of outcomes $R$ in a certain range of conditions $C$ entails attaining a high rate of success with respect to $\mathrm{R}$ in $\mathrm{C}$ across a set of relevantly close possible worlds (Greco (2010), 77). 
concluding the paper with some remarks on the scope and strength of the overall claim that I am advancing here.

\section{Objections and Clarifications}

\section{Personal relationship with God}

An important potential objection to (2) concerns the seeming inability of individuals in non-theistic cultures to have a meaningful personal relationship with God during their earthly lives. One might well think that having such a relationship would require having explicit theistic belief, which in turn suggests that God would not want to create the human race with a tendency to end up with divergent sets of beliefs about the character of the divine reality. I want to try to cast doubt on this thought, however. My suggestion is that individuals who lack explicit theistic belief - the belief that there exists an omnipotent, omniscient, perfectly good person who created the universe - might nevertheless be able to relate personally to God under a more limited description. The basic line of thought here is a familiar one, ${ }^{15}$ but I wish to develop it in some novel ways.

For a person to relate to God without realizing that it is God with whom she is in relationship would be for her to relate de re to God. That is, she wouldn't self-describe her situation in terms of 'engaging in relationship with God', since she wouldn't realize that it is God to whom she is relating, even though relationship with God would in fact be what is occurring. But since it may be less than obvious that it is even possible to engage in personal relationship with $\mathrm{X}$ without realizing that one is in relationship with $\mathrm{X}$, let's first look at what seems to be a human-to-human case of de re relationship: ${ }^{16}$

Molly and Ted work in the same office building, but have never spoken to one another. One day, whilst staring out across the office in idle moment, Ted notices that Molly appears to be extremely stressed. On top of all her other responsibilities, she has just been assigned the burdensome task of stuffing hundreds of envelopes with invitations for an upcoming promotional event. When everyone else including Molly has gone home, Ted decides to stay late and stuff the envelopes for Molly, leaving only an anonymous note: 'I saw you looking a bit overworked - I hope this helps.' When Molly comes in the next morning and finds the note with the completed pile of envelopes she feels deep gratitude to the person who did this kind thing for her. She goes out and buys an expensive box

15. See Wainwright (2002), 193; Poston and Dougherty (2007); 193, Moser (2004), 58. Notaby, the theologian Karl Rahner held that it is possible for a non-Christian to be an 'anonymous Christian'; to possess saving faith in the God of Christianity through an implicit awareness of God which is ubiquitous (Rahner (1976), 283). C.S. Lewis may have at least had toyed with a similar idea in the final instalment of his Narnia Chronicles, The Last Battle.

16. The following case has some similarities with one described by Poston and Dougherty (2007), 192-193. 
of chocolates, and leaves them in the break room with a note: 'These are for the lovely person who helped me out yesterday - thank you so much!' Once everyone else is out of sight, Ted gratefully takes the gift, and replaces it with another note of his own: 'Thank you for these! I'm glad to have been able to help.' We can imagine that they carry on in this fashion for a while until Molly finally learns that her anonymous helper was Ted, whereupon the two of them begin to engage in friendship in the more usual sorts of ways.

Molly in this case starts out by personally relating de re to Ted. She wouldn't have described her situation in terms of 'relating to Ted', since she didn't recognize the person who helped her out as Ted, but a personal relationship with Ted was nonetheless what was really going on. Now, I want to suggest that if God exists, something analogous to this case can and likely does occur between God and many human beings who recognize God only under a limited description. Clearly enough, though, it matters a good deal which descriptions someone uses to pick out God. When Molly is relating de re to Ted, the description she uses in thinking about Ted is something like the person who helped me out yesterday at a really stressful time. It is in virtue of her thinking about Ted under this description that she is liable to feel such gratitude towards him and to want to express her gratitude towards him in the sorts of ways that she does. If instead Ted had not helped out Molly in this way, but rather, had (say) merely disposed of the used coffee cup on her desk, and if Molly had thought about the person who disposed of my used coffee cup, she would presumably have felt a far weaker and more fleeting sort of gratitude towards Ted than she in fact did feel towards him and she presumably would not have been motivated to engage in the sorts of expressions of gratitude that she did.

A similar point seems to be true of the divine-human case. Only some of the infinitely many definite descriptions that God satisfies, if he exists, are such that if one thinks about God under those descriptions, then one will be able and liable to express the appropriate sorts of emotional attitudes towards God. The descriptions I have in mind might include the moral lawgiver, the ground of being, the creator of the universe (or some specific part thereof), The Good. A person who feels emotions of awe and wonder towards the creator of the universe will thereby be feeling those attitudes de re towards God. The same is true of the person who feels gratitude towards the ground of my being. The sort of gratitude that is involved here is plausibly the sort of gratitude that would be fitting for a person to have towards God if God exists - that is, gratitude for one's very life and the good things it contains. Again, if someone strives to obey the moral lawgiver, then her striving will be directed de re towards God.

One might very reasonably wonder, though, how de re relationship with God is supposed to work in cases where the human party to the would-be relationship has substantially false beliefs about who it is that satisfies descriptions like the moral lawgiver and the creator of the universe and so on, or in cases where such 
descriptions are included within more detailed descriptions that are overall false of God, for instance, the moral lawgiver who placed the earth on the back of an elephant. I want to attempt to develop a couple of thoughts about how this worry might be addressed.

One thought is this. There may be some such cases - though perhaps not all will be like this - in which a human subject uses descriptions that God does not satisfy and yet the subject nonetheless succeeds in picking out God by employing those descriptions in the purely referential manner to which Keith Donnellan (1966) has drawn attention. ${ }^{17}$ There appear to be at least a couple of mechanisms by which a subject might succeed in picking out a certain object with a definite description despite the fact that the description is false of that object.

For one thing, it might be that the subject who is using the description has some kind of direct cognitive contact with the object and is merely using the definite description as a means of ostension. By 'direct cognitive contact', I mean that the object is in some way present to the consciousness of the subject, perhaps as an object of her perception or as a proximate cause of some salient aspect of her perceptual experience. ${ }^{18}$ In a case in which the subject has direct cognitive contact with God in some such manner, the subject might use a description that is false of God and yet because the description is simply a means of 'pointing to' the object of her experience, she nonetheless succeeds in referring to God.

Another mechanism might be as follows. Suppose the subject employs a description involving several properties - for instance, the $x$ which is $F, G$, and $\mathrm{H}-$ some of which are possessed by the object in question and some which are not. The mechanism by which the subject succeeds in referring to the object with that description might be the greater salience, in the context at issue, of the properties that are possessed by the object as compared with the properties that aren't. ${ }^{19}$ What I mean is this. Recall the case of Molly and Ted. Suppose that Molly is gratefully reflecting upon her pleasant discovery of the pile of stuffed envelopes with the anonymous note, and suppose that she mistakenly assumes that the person who is responsible is a woman, but that that assumption isn't playing much of a role at all in causing her to feel grateful for the kind deed. The description Molly is using in thinking about her anonymous helper is the $x$ who is a woman and who kindly stuffed the envelopes for me. But it isn't too implausible, I

17. Donnellan suggests, for instance, that a partygoer who points to a gentleman the other side of the room and asks 'Who is the man drinking a martini?' has successfully referred to the intended individual, even if the individual in question is actually drinking water rather than martini (Donnellan (1966), 287). The explanation is that the description here 'is merely one tool for doing a certain job - calling attention to a person or thing - and in general any other device for doing the same job, another description or a name, would do as well' (Donnellan (1966), 285).

18. Someone might have direct cognitive contact with God by way of a perceptual religious experience of the sort Alston (1991) discusses, or an experience of a striking and unusual event that is proximately caused by God's special, local activity.

19. Thanks to Trent Dougherty for raising this suggestion in conversation. 
think, that Molly's gratitude is still directed towards Ted, even though Ted is not a woman. And the reason is that the property of being the $x$ who stuffed the envelopes for Molly is significantly more salient than the property of being a woman in the context at issue: Molly's belief that someone possesses the former property plays a much greater role in causing her feeling of gratitude than does her belief that someone possesses the latter property. Similarly, it might be that in some cases in which a person uses a description involving some properties that God possesses and some that God doesn't possess - for instance, the $x$ who created the universe and who made the earth flat - those properties that God does possess are more salient than those that God doesn't possess, in the sense that the subject's beliefs about the properties that God does possesses are playing a much greater role in generating her feelings of gratitude, reverence, awe, or whatever.

Perhaps, though, there remain some recalcitrant cases in which neither of these two mechanisms is plausibly exemplified. Perhaps, that is, there are some cases in which the human subject's descriptions fail altogether to pick out God. Still, even if her descriptions are such that she fails to refer to God, there may yet be a kind of quasi-relationship with God that is available to her. ${ }^{20}$ Consider the following case:

Gracie, like many children, has been told that Santa Claus is the person who brings her Christmas presents each year. She has been told all about Santa's Lapland dwelling, his portly appearance and his red and white outfit, and his impressive ability to distribute Christmas presents across the entire globe in a single evening. Of course, the person who really brings the Christmas presents each year is Gracie's father, Bill. But let's grant that in thinking about Santa, Gracie doesn't even implicitly have her father in mind; she doesn't refer to him by the name 'Santa'. Now, Gracie knows that the person who brings the Christmas presents is to be thanked. (This is the analogue of a religiously relevant proposition such as that the person who created the universe is to be thanked.) But since she also believes that the person who brings the Christmas presents = Santa Claus, let's grant that her feelings of gratitude are directed towards the non-existent Santa rather than towards her father, Bill. Nonetheless, Bill, knowing his daughter's character intimately, knows that were Gracie to be apprised of the true identity of the person who brings the Christmas presents, she would direct her gratitude towards him (i.e. Bill). Bill thus chooses to 'count' Gracie's gratitude as though it were rightly directed towards him. Seeing Gracie's delight and thankfulness towards Santa when she opens her presents, Bill is deeply gladdened. And whenever Gracie sends a thank you note to Santa, Bill replies to it warmly in what Gracie takes to be Santa's hand. Eventually Gracie learns of the non-existence of Santa and of the fact that her father was really the person who brought the Christmas presents each year and replied to her thank you notes. Once she has got over the

20. De Ridder and van Woudenberg (2014) express scepticism about the idea that adherents of nonAbrahamic religions could refer to the God of Abrahamic monotheism if he exists. This final proposal of mine is supposed to work even granting that such scepticism is well-founded. 
initial shock, Gracie comes to see those episodes in which she had thought she was interacting with Santa as something to be deeply cherished for what they show of her father's love for her.

Similarly, God might very well count the expressions of gratitude, reverence, and obedience that a human being directs towards some non-existent deity as though they were directed towards God, so long as God knows that she would direct those same attitudes towards him were she apprised of the true identity of the moral lawgiver, the creator of the universe, and so on. Now, even if one insists that in the case just described Gracie was not in any way relating to her father during those episodes when she thought she was relating to Santa, it seems hard to deny that those episodes retrospectively take on an importance within her relationship with her father once she becomes apprised of what was really going on. In that sense, those episodes make an important contribution to the value of her relationship with her father. Likewise, episodes during which a person takes herself to be engaging in relationship with some non-existent deity (without thereby referring to God) could come to have a similar retrospective significance - if indeed it was really God who was causally responsible for that which she took the non-existent deity to be responsible for - once she meets God 'face-to-face'.

Significantly, this latter suggestion seems to be applicable even to cases in which the human subject does not believe in the existence of any supernatural persons whatsoever. Suppose that Anders is an atheist for whom theism has never been a live option. Anders believes that he owes his existence to an impersonal source, but often feels a deep sense of gratitude towards the source of his blessings. Anders seeks to live a life that expresses his deep sense that the good things in his life are in some sense a gift that he has not earned. If God exists, then God is in fact the source of Anders' blessings. Suppose we grant that Anders cannot be said to be grateful to God - not even de re - since the impersonal object that Anders believes to be the source of his blessings, namely, the cosmos, is too unlike God in its metaphysical nature. ${ }^{21}$ Still, it could very well be true that if Anders were to come to believe that God rather than a set of impersonal forces is the source of his blessings, then Anders would direct his attitude of thankfulness towards God. God, knowing this counterfactual truth about Anders, could count Anders' feelings of gratitude as though they were directed towards God. True, Anders had previously not thought of the source of his blessings in personal terms, but we can imagine nonetheless that once he becomes apprised of the true identity of the source of his blessings, that those earlier episodes in which he felt and sought to express his gratitude could come

21. Benjamin Cordry suggests that it is implausible to ascribe to a human subject de re attitudes towards God in cases where the human subject has an ontology that doesn't include anything like God (Cordry (2008), 17-18). 
to take on a deep retrospective significance within his relationship with God once he is able to say 'It was you all along!'

Still, even supposing de re relationship with God could be as widely available as I have claimed, wouldn't it be unfair of God to permit a situation in which the level of awareness of God that is available to people in various parts of the world is subject to such variation, and therefore quite unlikely that God would permit such an uneven geographical distribution of explicitly theistic belief? Well, consider that on versions of theism on which there is an afterlife and on which the opportunity to spend that afterlife in the presence of God is extended to all who have not explicitly and knowingly rejected God at the end of their earthly lives, the differences between various individuals' levels of awareness of God during this lifetime will pale in comparison to the difference between the keenest awareness of God that is available in this lifetime and the awareness of God that will be available in the life to come. ${ }^{22}$ If we add to this the thought that, at least given specifically Christian versions of theism, God wants human beings to participate in the task of communicating special revelation to the world, it doesn't seem unlikely that God would permit a situation in which the level of awareness of God that is available during this lifetime to individuals across various parts of the world is subject to significant variation.

\section{God's failure to speed up the testimonial transmission process}

Another potential worry is this: one wonders, given his omnipotence, why God couldn't have ensured that theistic belief more rapidly and more thoroughly permeated the earth's populations than it actually has done, whilst at the same time still managing to secure a desirable balance between those competing goods outlined in the previous section? That is a very natural worry. However, I suspect that were we to try to sharpen up the worry here, it would end up being parallel to a complaint that is sometimes raised in debates about the problem of evil: namely, that there is some minimum number of horrific occurrences such that that number of horrors but no more than that number is necessary for bringing about the goods that God desires to realize, and that it seems that there have actually occurred more than that minimum number of horrors. But in fact, it is quite plausible that there is no such non-arbitrary minimum, either in the case of horrors or in the case of the uneven distribution of theistic belief. Let $n$ represent the number of people whom the testimonial transmission of explicitly theistic belief fails to reach (or at any rate, for whom such testimony is not successful in rendering explicitly theistic belief a live option). For any $n$, if the existence of $n$ unreached individuals is consistent with God's realizing the

22. Christian theism notably involves the idea that there will be an enormous difference between the level of awareness of God available to anyone during this lifetime as compared with the next. Saint Paul writes that 'For now we see through a glass, darkly; but then face-to-face: now I know in part; but then shall I know even as also I am known' (1 Corinthians 13:12). 
favourable balance of competing goods that he wishes to realize through permitting humans to be significantly mutually epistemically dependent, then the existence of $n-1$ unreached individuals would be equally consistent with God's realizing a favourable balance of the aforementioned goods, as would the existence of $n+1$ unreached individuals. ${ }^{23}$ If God allows testimonial beliefforming practices to play any role at all in the propagation of theistic belief, as I have suggested he has good reason to do, then some amount of uneven distribution (both temporal and spatial) is unavoidable, and it would seem that there is no non-arbitrary threshhold amount such that he ought to allow no more than that amount.

\section{Conclusion}

I have argued that we have good reason to think that (1) $\operatorname{Pr}(E \mid M E D)$ is high and that (2) $\operatorname{Pr}(\mathrm{MED} \mid$ theism) isn't much lower than $\operatorname{Pr}(\mathrm{MED} \mid$ naturalism). We therefore have good reason to doubt that $\operatorname{Pr}(\mathrm{E} \mid$ theism $)$ is much less than $\operatorname{Pr}(\mathrm{E} \mid$ naturalism $)$, and hence to doubt Maitzen's contention. In closing I should like to make some final remarks concerning the scope of my argument.

I conceded at the outset that the theistic explanation I have offered here for $\mathrm{E}$ doesn't fully explain E, which is why I claim only that this explanation, if plausible, casts significant doubt Maitzen's contention rather than refuting it outright. In particular, whilst the story on offer here postulates God's reasons for wanting human beings to be mutually epistemically dependent, the story I have offered doesn't purport to explain why God would want humans to exemplify all the specific cognitive mechanisms that are in fact involved in our mutual epistemic dependence, some of which (according to current cognitive science of religion) make humans prone in the absence of certain kinds of cultural input to adopt what are (from the point of view of theism) substantially erroneous conceptions of the supernatural, involving limited and morally imperfect deities and spirits. ${ }^{24}$ Jason Marsh (2013) has argued that these considerations raise a 'problem of natural non-belief'; a problem of why a loving God would allow humans to be cognitively constituted in such a way that our default religious stance (apart from certain kinds of cultural input) is much nearer to animism and polytheism than it is to belief in an omnipotent, omniscient, morally perfect God. So while the theistic explanation I have offered for E goes a significant way towards accounting for the fact that divergent sets of religious beliefs are found geographically 'clustered' according to culture rather than being evenly smattered across the surface of the globe, it doesn't attempt to address Marsh's problem of

23. This parallels Peter van Inwagen's response to the 'minumum number of horrors' objection (van Inwagen (2006), 106).

24. See Barrett (2010), 97. 
natural non-belief. For that reason, an additional explanation - one that postulates God's reasons for permitting this aspect of $E$ to which Marsh draws attention - would be needed in order to fully explain E.

But is it not worrying that theists need to invoke such a plurality of explanatory mechanisms in trying to account for $\mathrm{E}$, whereas the naturalist merely needs to invoke a combination of bio-psychological and cultural factors, factors which the theist (this one at any rate) already grants? Isn't it the case that, even supposing the theist can come up with other explanations which (in conjunction with something like the one offered in the present paper) suffice to explain E, the theist is burdened with a considerably less parsimonious and hence intrinsically less probable account of $\mathrm{E}$ ?

Firstly, the parsimony or simplicity of a hypothesis is generally held to be a property that it possesses relative to a given body of evidence. ${ }^{25}$ That is, even supposing a hypothesis $\mathrm{H}_{1}$ is a more complex way of accounting for some evidence $\mathrm{E}_{1}$ than a rival hypothesis $\mathrm{H}_{2}$ is, it doesn't follow that $\mathrm{H}_{1}$ is a more complex way of accounting for the evidence than $\mathrm{H}_{2}$ when the evidence under consideration is widened to include $E_{1} \& E_{2} \& E_{3} \& \ldots E_{n}$. So even supposing that the theistic explanation of the lopsided distribution of theistic belief is more complex than the naturalistic explanation of that phenomenon, it doesn't follow that theism is less simple than naturalism when the evidence under consideration is widened to include all the other evidence for which these competing hypotheses seek to account: the existence of a complex, life-friendly physical universe, the conformity of material objects to natural laws, the existence of consciousness, and so on.

Secondly, explanations of a given occurrence which appeal to the agency of a person are often more complex than explanations that invoke purely nonpersonal physical causes, at least in a certain sense. In particular, the former often appeal to a wider array of possible explanatory mechanisms than the latter, and yet the former are not necessarily less intrinsically probable than the latter for all that. The following example should illustrate the point. Suppose one is trying to explain the fact that the gnome in one's front garden has been knocked over during the night. One hypothesis is simply that the wind blew it over. Another hypothesis is that a person deliberately pushed it over, and one will presumably want to fill out this hypothesis with a range of possible reasons that a person might have had for committing such an act. There is an important sense in which the latter hypothesis is more complex than the former - it certainly involves more moving parts than the former - and yet it isn't obvious that the latter is much less intrinsically probable than the former. More generally, if a certain hypothesis already includes the agency of a person, as the hypothesis of theism does, then it isn't obvious that by filling out the hypothesis

25. See, for example, Swinburne (1998), 42. 
with a wide range of possible reasons that the person might have had for bringing about (or permitting) the occurrence at issue, that one is thereby complexifying one's hypothesis in a way that substantially drives down its intrinsic probability. ${ }^{26,27}$

\section{References}

Alston, William P. (1991) Perceiving God: The Epistemology of Religious Experience (Ithaca NY: Cornell University Press).

BAEHR, JASON S. (2011) The Inquiring Mind: On Intellectual Virtues and Virtue Epistemology (Oxford: Oxford University Press).

BARRETT, JUSTIN L. (2010) 'Cognitive science, religion, and theology', in Jeffrey Schloss \& Michael J. Murray (eds) The Believing Primate: Scientific, Philosophical, and Theological Reflections on the Origin of Religion (Oxford: Oxford University Press), 76-99.

(2011) Cognitive Science, Religion, and Theology: From Human Minds to Divine Minds (West Conshohocken PA: Templeton Press).

BOyer, PASCAL (2001) Religion Explained: The Human Instincts That Fashion Gods, Spirits, and Ancestors (London: Heinemann).

BUCHAK, LARA (2014) 'Rational faith and justified belief', in Timothy O'Connor and Laura Frances Callahan (eds) Religious Faith and Intellectual Virtue (Oxford: Oxford University Press), 49-73.

BYERLY, T. RYAN (2014) 'The special value of epistemic self-reliance', Ratio, 27, 53-67.

CORDRY, BENJAMIN S. (2008) 'Divine hiddenness and belief de re', Religious Studies, 45, 1-19.

CRAIG, WILLIAM LANE (1989) 'No other name: a middle knowledge perspective on the exclusivity of salvation through Christ', Faith and Philosophy, 6, 172-188.

DE RIDDER, JEROEN \& VAN Woudenberg, RENÉ (2014) 'Referring to, believing in, and worshipping the same God: a reformed view', Faith and Philosophy, 31, 46-67.

Donnellan, KeIth S. (1966) 'Reference and definite descriptions', The Philosophical Review, 75, 281-304.

Dougherty, Trent (2014) The Problem of Animal Pain: A Theodicy for All Creatures Great and Small (Basingstoke: Palgrave Macmillan).

Drange, THEODORE (1991) 'The argument from non-belief', Religious Studies, 29, 417-432.

FrICKER, ElizABETH (2006) 'Testimony and epistemic autonomy', in Jennifer Lackey and Ernest Sosa (eds) The Epistemology of Testimony (Oxford: Oxford University Press), 225-244.

Greco, JoHn (2010) Achieving Knowledge: A Virtue-Theoretic Account of Epistemic Normativity (Cambridge: Cambridge University Press).

HiCK, JOHN (1979) Evil and the God of Love (Glasgow: Collins).

HowARD-SNYDER, DANIEL (1996) 'The argument from divine hiddenness', Canadian Journal of Philosophy, 26, 433-453.

Howard-SNYder, DANiEl \& Moser, PAUl K. (eds) (2002) Divine Hiddenness: New Essays (Cambridge: Cambridge University Press).

26. Many thanks to Brian Leftow, Trent Dougherty, John Hawthorne, Tim Mawson, Wes Skolits, Christopher Kyle, Rik Peels, Matthew Benton, Billy Dunaway, Isaac Choi, Dani Rabinowitz, C'Zar Bernstein, the audience at the $3^{\text {rd }}$ Glasgow Philosophy of Religion Seminar, and an anonymous referee for this journal for helpful feedback on this article.

27. This paper was made possible through the support of a grant from the John Templeton Foundation. The views expressed in this paper are those of the author and do not necessarily reflect the views of the John Templeton Foundation. 
KAHNEMAN, DANiEL (2003) 'A perspective on judgment and choice: mapping bounded rationality', American Psychologist, 58, 697-720.

(2013) Thinking, Fast and Slow (New York: Farrar, Strauss, and Giroux).

Maitzen, Stephen (2006) 'Divine hiddenness and the demographics of theism', Religious Studies, 42, 177-191.

(2008) 'Does Molinism explain the demographics of theism?', Religious Studies, 44, 473-477.

MARSH, JASON (2008) 'Do the demographics of theistic belief disconfirm theism? A reply to Maitzen', Religious Studies, 44, 465-471.

(2013) 'Darwin and the problem of natural nonbelief', The Monist, 96, 349-76.

MAwson, T. J. (2012) 'The rationality of classical theism and its demographics', in Yujin Nagasawa (ed.) Scientific Approaches to the Philosophy of Religion (London: Palgrave Macmillan), 184-204.

Moser, Paul K. (2004) 'Reply to Schellenberg', in Michael L. Peterson \& Raymond J. Van Arragon (eds) Contemporary Debates in the Philosophy of Religion (Oxford: Blackwell), 56-58.

Poston, Ted \& Dougherty, Trent (2007) 'Divine hiddenness and the nature of belief', Religious Studies, 43, 183-198.

PRITCHARD, DUNCAN (2013) 'Epistemic virtue and the epistemology of education', Journal of Philosophy of Education, 47, 236-247.

RAHNER, KARL (1976) Theological Investigations, XIV (London: Darton, Longman \& Todd).

ReID, Thomas (1997) An Inquiry into the Human Mind on the Principles of Common Sense (Edinburgh: Edinburgh University Press).

ROBERTS, ROBERT C. \& WOOD, W. JAY (2007) Intellectual Virtues: An Essay in Regulative Epistemology (Oxford: Oxford University Press).

Schellenberg, J. L. (1993) Divine Hiddenness and Human Reason (Ithaca NY: Cornell University Press).

(2007) The Wisdom to Doubt: A Justification of Religious Skepticism (Ithaca NY: Cornell University Press).

Simpson, Thomas W. (2012) 'What is trust?', Pacific Philosophical Quarterly, 93, 550-569.

Stump, EleONORE (2010) Wandering in Darkness: Narrative and the Problem of Suffering (Oxford: Oxford University Press).

Swinburne, Richard (1998) Providence and the Problem of Evil (Oxford: Oxford University Press).

VAn Inwagen, Peter (2006) The Problem of Evil: The Gifford Lectures Delivered in the University of St Andrews in 2003 (Oxford: Oxford University Press).

WAINWRIGHT, William J. (2002) 'Jonathan Edwards and the hiddenness of God', in Daniel Howard-Snyder \& Paul K. Moser (eds) Divine Hiddenness: New Essays (Cambridge: Cambridge University Press), 88-119.

ZagZEBSKI, Linda (1996) Virtues of the Mind: An Inquiry into the Nature of Virtue and the Ethical Foundations of Knowledge (New York: Cambridge University Press). 